\title{
IMPACT OF EUROPEAN LEGISLATION AND CASE-LAW ON ELIMINATION OF DISCRIMINATION IN EMPLOYMENT RELATIONS IN EU
}

\author{
Tomáš PERÁČEK, PhD \\ Comenius University in Bratislava, Faculty of Management, Slovakia \\ peracek2@uniba.sk
}

\begin{abstract}
The present scientific article examines the current state and issues of discrimination of selected groups of employees in employment relations. We deals with the current state of EU legislation and case law in the area of non-discrimination in employment relations. The main attention is given to the most important standardization activities of selected bodies of the European Union. We applied scientific methods of research such as analysis, synthesis, deduction, and comparison with regard to the nature of the topic studied. The scientific and doctrinal interpretation of the legislation in conjunction with the lessons learned from scientific literature and European case law has enabled us to find answers to the questions sought and the application problems of business practice. At the end of the article, we evaluate the results of our examination and propose ways of eliminating the identified causes of the lack of enforceability of the European Union's anti-discrimination policy.
\end{abstract}

Keywords: discrimination, employee, employer, European case law, European legislation,

\section{Introduction}

Any discrimination in employment relations as one of the socio-pathological phenomena is seen as an undesirable occurrence in today's modern and advanced European society. Despite its legislative prohibition, it is quite often present in the workplace. Discrimination, according to some authors such as (Kamaro et al. 2020) generally means discriminating or restricting an 
individual or a group of persons. It is understood as any unjustified unequal treatment of people from the state or other people who have certain power, authority or competence in environments where people depend on one another in a way. Such an environment is also a working environment where we often encounter various forms of discrimination.

The issue of equal treatment in the light of experience Jankelová et al. (2018) despite a long-standing social debate, is met with general public disinterest. This fact, in our view, causes the overall disinterest mainly of legal theorists, but also of top managers, to deal more closely with the issue of equality as such. Only selected experts in the field of labour law of the European Union are looking further at this problem. At present, however, legislative elimination of discrimination is a key task not only for European legislation but also for the legislation of individual Member States, which should determine the final "rules of the game" in employment relations. For this reason, too, we want to contribute with this scientific article to a comprehensive view of the elimination of discrimination in employment relations in the European labour market in the context of existing European legislation and case law.

\section{Theoretical background}

The prohibition of discrimination in the democratic and advanced states of the world, including the legal area of the Member States of the European Union, is one of the cornerstones of their modern laws. Implementation and effective enforceability of anti-discrimination principles creates conditions for smooth functioning of legal relations, employment and social relations according to Funta (2018). In the academic and scientific literature and pursuant to a number of important international and national documents, Srebalová \& Vojtech (2021) consider as discriminatory practices in particular those which disadvantage or restrict an individual or group of persons on grounds of their sex, racial origin, ethnic origin, national origin, colour, language, age, sexual orientation, belief, religion, political or any other opinion, national or social origin, nationality or ethnic group, property, gender or other status.

Based on the earlier case-law of the European Court of Justice in Case C-394/96 of 30 June 1998, discrimination means applying different rules in comparable situations as well as applying the same rule in different situations. Gender equality is a fundamental right and a fundamental value of a democratic society. It represents one of the important indicators of the degree of development of democracy and the application of democratic principles in a given society. In this 
regard, it points out Sararu (2008) however, the second aspect of gender equality, which is linked to the new challenges of sustainable economic development, economic growth and social cohesion, is no less important. Current and, in particular, future developments are mainly based on the creation of new and better jobs. Camaro et al. (2020) ares this view (2020) and notes that up to 3/4 of the new jobs created in Europe between 2015 and 2019 were filled by women.

Anti-discrimination legislation at European Union level consists of a significant number of legislative acts, whether primary or secondary. Specific commitments in this area stem from directives of the European Parliament, the Council or the European Commission for Member States. These are the sources of secondary Community law which have a supranational character. They're according to Tekle (2020) part of the adaptation of the first pillar of the European Union - the internal market policy of the European Communities.

\section{Objective and methodology}

The purpose of the contribution is to examine selected legal aspects of the prohibition of discrimination with a focus on the current legislative regulation and related problems in the Member States of the European Union. In addition to the main target, we have also chosen milestones:

- to analyse the chosen case law of the European Court of Justice and its contribution to the elimination of discrimination in employment relations;

- to critically assess the current European legislation on the prohibition of discrimination and, if necessary, make proposals for a “de lege ferenda", i.e. legislative proposals for improvement.

We want to achieve the stated target and milestones, in particular, through a thorough study of relevant European legislation, both academic and scientific literature and the case law of the European Court of Justice. Due to the nature of the scientific article, we use a number of scientific methods of knowledge suitable for the knowledge of the law. This concerns, in particular, the use of a critical analysis method to examine legal regulation and abstraction. Using the comparative method, we make available different opinions of lawyers, economists as well as managers in the field and management of human resources not only on the appropriateness of regulation but also on the interpretation of individual legal concepts. In this way we strive for a beneficial managerial 
and legal view of the examined issue of non-discrimination in employment relations. Due to our own years of experience in the practice of law and in the field of european labour law we also use doctrinal interpretation.

\section{Results and Discussion}

The application of the principle of non-discrimination in its provisions pays particular attention not only to secondary law, but also to primary European Union law. In the text of Article 13 of the Treaty establishing the European Community, the Council, acting unanimously on a proposal from the Commission and after consulting the European Parliament, may adopt measures to combat discrimination based on sex, racial or ethnic origin, religion or belief, disability, age or sexual orientation. In this context Dudić et al. (2020) points out that, under Article 141 of the Treaty, each Member State is required to ensure that the principle of equal pay for men and women for equal work or work of equal value is applied. To this end, 'pay' means the usual basic or minimum wage or salary and any benefits paid directly or indirectly by the employer, in cash or in kind, to an employee in employment. In point 4 of Article 141, according to some authors Fletcher (2020) the principle of positive discrimination against employees on grounds of sex and in order to maintain or introduce measures allowing for specific advantages for the underrepresented sex for easier pursuit in a professional activity or to prevent or compensate for disadvantages in professional careers is declared.

According to the rulings of the European Court of Justice, the remuneration for work is also considered to be compensation of wages, employer contributions to employees under private (but not state) pension insurance, severance pay at termination of employment, or right to a discount on fares for pensioners. In Case No 43-75 Defrenne v Sabena concerning the determination of equal pay between male and female workers, the Court of Justice, by its judgment of 4 April 1976, established that Article 141 of the Treaty establishing the European Community has a horizontal direct effect and may therefore be invoked by an employee vis-à-vis the employer. It is not important whether the employer is a private or a public body.

A thorough analysis of the legal institute of non-discrimination in employment relations regulated by Community law concludes that its internal structural breakdown is multi-spectral. In our view, this means that it is addressed by various social and legal relations. Further decryption offers, in particular, an environment of secondary law, where numerous European Union directives 
regulate, for example, access to employment, working conditions, termination of employment, protection of dignity in employment relations, prohibition of sexual harassment, the status of men and women in social security systems and some others.

In the context of these facts, Klimek \& Funta (2021) points out that since the enlargement of the European Union in 2004 to include several countries of Central and Eastern Europe, according to several expert studies, the Roma have been the most vulnerable group within the European community as well as citizens from the countries of the former Soviet Union. They are regularly, according to Troitiño et al. (2018), the target of racial attacks, xenophobic behaviour or discrimination in particular in civil and labour relations. Several discriminatory tendencies with an impact on the labour law and social spheres in European society are also highlighted by Gabriel and Schmitz (2020) Annual reports of the European Monitoring Centre on Racism and Xenophobia.

As early as 2006, Decision No 771/2006 of the European Parliament and of the Council establishing a European Year of Equal Opportunities for All (2007) - towards a just society - was adopted. Luril (2008) considers that the conclusions point to the fact that, despite significant progress in promoting equality and combating discrimination, both phenomena in negative terms persist in society in various forms. The Council's evaluation resolution of December 2007 concluded that, in order to make real progress in ensuring equality in practice, the general awareness, the enforceability of the legislation, the mutual cooperation of the Member States should be strengthened, as well as the efforts to implement the European Pact for Gender Equality and the Community Plan for equality between men and women for the years 2016 to 2020. The promotion of equality between men and women has long been an essential role for the Community beyond the above-mentioned years.

\section{Secondary European legislation}

European Union secondary law governing the area of non-discrimination and equal treatment is specified in numerous European Union directives and several authors (Krisstinson et al., 2020) agree that the principle of equal treatment is the most popular product of the legislative process of European Union law.

In our opinion, we can divide the anti-discrimination directives into several groups, considering the so-called anti-discrimination directives in the narrower sense, but also in a broader sense. The 
extensive interpretation of these directives, although not directly regulated by the issue of nondiscrimination (Council Directive 86/378/EEC on the implementation of the principle of equal treatment between men and women in occupational social security schemes), nevertheless makes a very significant contribution to this prohibition.

The development of European anti-discrimination policy is relatively dynamic, both in a comprehensive evaluation and with particular regard to the field of labour relations. In recent years, Member States' legal systems have been strengthened by a number of progressive legal institutes through a number of directives. Directive 2006/54/EC of the European Parliament and of the Council on the implementation of the principle of equal opportunities and equal treatment of men and women in matters of employment and occupation represents a significant change in the current context. Pursuant to point (1) of Article 34 of its text, it replaces and repeals Directives 75/117/EEC, 76/207/EEC, 97/80/EC and 86/378/EEC with effect from 15 August 2009. We also consider it necessary to point out that Directive 2006/54 is a subsumation of the repealed directives into a single 'mutatis mutandis' legal document, but it also introduces some new elements.

Before we proceed to the analysis of Directive $2006 / 54 / \mathrm{EC}$, as a still central antidiscrimination labour law document of the European Community, we consider it necessary at least to outline, in historical contexts, the most important contribution of the directives of the second half of the twentieth century. Directive 75/117/EEC on the approximation of the laws of the Member States relating to the application of the principle of equal treatment to the remuneration of men and women was adopted on 10 February 1975. In its Article 1, it stated that the principle of equal pay for men and women, laid down in Article 119 of the Treaty establishing the European Community, implies the elimination of any discrimination on grounds of sex in respect of all aspects and the conditions of remuneration for equal work or work to which equal value is attached. The Directive did not contain a comprehensive normative text (consisting of 10 articles in total), but obliged Member States to use a system of qualifications in employment to be based on the same criteria for both men and women and to exclude any form of discrimination. As it adds Peráček et al. (2020), it also included an undertaking addressed to the Member States to introduce guarantees in their national legal systems for any employee who is deemed to be harmed as a result of the non-application of the principle of equal pay to claim his rights in court. The principle of equal treatment between men and women in pay for work was originally laid down in Article 119 
of the Treaty establishing the European Community. The Treaty of Amsterdam was renumbered in 1996 and was subsequently enshrined in Article 141.

Directive 76/207/EEC on the implementation of the principle of equal treatment between men and women as regards access to employment, vocational training, promotion and working conditions of 9 February 1976 deepened the content of the concept of equal treatment by excluding any direct or indirect discrimination on grounds of sex, in particular by reference to marital or family status. The application of the principle of equal treatment meant that there should be no discrimination on grounds of sex in terms of conditions of access, including selection criteria, to any posts or positions, regardless of field or sector of activity, and to any levels of employment hierarchy.

The concept of indirect discrimination was first defined in Directive 97/80/EC of 15 December 1997 on the burden of proof in the case of discrimination on grounds of sex. Article 2(2) states that indirect discrimination occurs where a clearly neutral provision, criterion or practice puts a substantially larger proportion of persons of one sex at a disadvantage, unless that provision, criterion or practice is appropriate and necessary and cannot be justified by objective non-sex related factors. The directive provided that, where persons who are considered to be harmed because the principle of equal treatment has not been applied to them, the facts from which it can be inferred that there has been direct or indirect discrimination appear before a court or other competent authority, it shall be up to the defendant to prove that there has been no breach of the principle of equal treatment.

Mura \& Kajzar (2018) points out that the concepts of direct and indirect discrimination are currently contained in several Community directives. Within the meaning of point 2 of Article 2 of Directive 2000/43/EC, direct discrimination is to be regarded as a case where one person is treated in a comparable situation less favourably than another, on grounds of racial or ethnic origin, and indirect discrimination is deemed to be discrimination where, as a result of an outwardly neutral rule, criterion or custom, a person of a particular race or ethnic origin would be disadvantaged in comparison with other persons.

Directive 2000/78/EC defines direct discrimination as more adverse treatment of one person as being treated by another. Indirect discrimination is the case where an apparently neutral provision, criterion or practice would place persons of a particular religion or belief, with a particular disability, a certain age or a particular sexual orientation at a disadvantage compared 
with others. It follows from the foregoing, according to Troitiño et al. (2018), one of the differentiating features of the concept of direct discrimination and indirect discrimination is that it is sufficient for less favourable treatment in a comparable situation to affect one person in the case of direct discrimination and that, in the case of indirect discrimination, it is sufficient that only Directive 97/80/EC in Article 2 in the context of the definition of indirect discrimination enshrines that less favourable treatment by sex is to affect a substantially larger proportion of members of one sex.

According to existing literature (Heath \& Di Stasio, 2020) as well as the available case law of the European Court of Justice, the concept of indirect discrimination is characterized by:

1. it is a rule, regulation, decision or instruction that applies to all or a particular group of persons defined by general characteristics,

2. the implementation of this regulation, rule, decision or order results in different treatment,

3. such a difference in treatment disadvantages a certain discriminatory reason for a directly defined group of persons,

4. such difference in treatment is not justified by the pursuit of a legitimate objective or is not proportionate and necessary to achieve it, as is apparent from the judgment of the European Court of Justice in Case C-79-99.

\section{Analysis of European case law}

From the extensive case law of the European Court of Justice on the prohibition of discrimination, we consider it necessary to focus on selected judgments which have made a major contribution to the elimination of discrimination. It follows from the judgment of the European Court of Justice in Case C-167-73 Commission of the European Communities in French Republic that citizens from Member States of the Community have the right to access to employment and to pursue employment activities in another Member State to the same extent and under the same conditions as domestic workers.

Another judgment of the European Court of Justice in Case C-450/93 Eckhard Kalanke in Freie Hansestadt Bremen found that if a woman and a man are applying for the same post with a higher status and are equally qualified, giving a woman priority on the grounds that this is a field of work that shows a significantly lower representation of women is considered to be a discriminatory act on the basis of gender. 
A very frequent form of indirect discrimination is the language requirements for the performance of a certain type of work, as it is clear that these requirements can be better met, especially by domestic jobseekers. However, Council Regulation No. 1612/68/EEC on freedom of movement for workers within the Community allows for the introduction of qualification conditions relating to linguistic knowledge only if they are justified by the nature of the work to be carried out. However, language requirements must not serve as a pretext for excluding employees from other Member States. However, this regulation cannot be applied in absolute terms. We rely on the legal sentence of the European Court of Justice Judgment in Case C 379/87 Anita Groener versus Minister for Education and the City of Dublin Vocational Educational Committee. It follows that the requirement of a perfect knowledge of the national language of a Member State should not be regarded as discriminatory action if this is due to the nature of the work carried out, e.g. for teaching staff.

Recruitment may require the employer to establish different language criteria for the candidate that he/she must meet. However, in the light of the judgment of the European Court of Justice in Case C-281/98 Roman Angonese in Cassa di Risparmio di Bolzano SpA, they cannot be assessed solely on the basis of a specific confirmation.

The principle of nondiscrimination under the judgment in Case C-36-74 B.N.O. Walrave and L.J.N. Koch in Association Union cycliste internationale, Koninklijke Nederlandsche Wielren Unie et Federación Española Ciclismo is binding not only for the Member States of the Community but also for private employers and trade unions (non-state institutions). The introduction of such restrictions by private operators could hamper the functioning of the internal market.

In violation of the principle of equal pay for men and women he considers Peráček et al. (2020) According to the judgment of the European Court of Justice in Case 129/79 Macarthys Ltd in Wendy Smith, the granting of various advantages for work performance for the benefit of men and women may not always be the same, but for this purpose work can be equal.

As further pointed out by Oláh et al. (2020). on the basis of the judgment of the European Court of Justice in Case 96-80 J.P. Jenkins v Kingsgate (Clothing Productions) Ltd., the employer's decision, according to which the remuneration for part-time work of the same value is lower than that for full-time work, qualifies as discriminatory. 


\section{Legislative process to eliminate discrimination}

The Member States of the European Union have undertaken, pursuant to Article 33 of the Directive, to adopt by 15 August 2008 legislation and further measures to bring their national laws in line with the content of the Directive. Its primary objective is to ensure the implementation of the principle of equal opportunities and equal treatment of men and women in matters of employment and occupation. With effect from 15 August 2009, the Directive repeals and replaces Directives 75/117/EEC, 76/207/EEC, 86/378/EEC and 97/80/EC. Point 1 of Article 2 of the Directive defines a number of basic concepts. Direct discrimination means less favourable treatment of one person on grounds of sex than another who is or would be treated in a comparable situation. Indirect discrimination means a situation where a clearly neutral provision, criterion or practice has placed persons of one sex at a particular disadvantage compared to persons of the other sex, unless that provision, criterion or practice is objectively justified by a legitimate objective and the means of achieving that objective are proportionate and necessary.

Harassment means, according to the Directive, undesirable sex-related conduct with the intention or effect of violating the dignity of a person and creating an intimidating, hostile, degrading, dishonoring or offensive environment. Sexual harassment enshrines any form of unwanted verbal, non-verbal or physical conduct of a sexual nature with the intent or effect of violating the dignity of a person, in particular when creating an intimidating, hostile, degrading, dishonoring or offensive environment.

Theorists like Dudic et al. (2020) take the view that, in terms of historical context, one of the most significant interferences in German law was the transposition of Directive 97/80/EC. Member States have been ordered to take, in accordance with their national judicial systems, the necessary measures to ensure that, where persons who are deemed to be harmed by the nonapplication of the principle of equal treatment in their case indicate before a court or other competent authority the facts from which it can be inferred that there has been direct or indirect discrimination, it shall be proved by the defendant that there has been no breach of the principle of equal treatment. I mean, in essence, according to Žofčinová et al. (2018) it transferred the burden of proof to the defendant, which is unusual from the point of view of the existing judicial system.

Community law governing the principle of equal treatment very consistently requires that, in the event of litigation, the burden of proof is on the defendant. However, this does not apply to proceedings in which it is for the court or other competent authority (ex officio) to determine the 
facts of the case. These requirements are imposed on the national law of the Member States not only by Directive 97/80/EC but also by Directive 2000/43/EC, Directive 2000/78/EC and Directive 2002/73/EC.

In Article 19(1), Directive 2006/54/EC addresses this situation in an identical manner by leaving it to the defendant to prove that the principle of equal treatment has not been infringed. We note that the Directive on the implementation of the principle of equal opportunities and equal treatment of men and women in matters of employment and occupation, despite the fact that four other Community directives on equal treatment will be repealed as of 15 August 2009, does not weaken the regulation of the institute, but, on the contrary, plays a significant role in strengthening and clarifying it, in which it is for an ordinary citizen of the European Union much easier to navigate.

Directive 2006/54/EC will regulate separately the entire area of gender equality in employment; Directive 2004/113/EC on access to goods and services; Directives 79/7/EEC, 86/613/EEC, 92/85/EEC and 96/34/EC as amended by Directive 97/75/EC in the field of social security and maternity and parenthood protection. The most important changes introduced by Directive 2006/54/EC are according to Čajka et al. (2018):

1. the definition of equal pay conditions will not be limited in some cases (in line with the case law of the European Court of Justice) to situations where a man and a woman work for the same employer;

2. the principle of equal treatment will also apply more clearly to employees performing public service work and to civil servants;

3. extending the principle of protection of pregnant women and mothers, but also men when returning from parental leave to work (which applies not only to the right to return to their original job, but also to the application of the same working conditions);

4. the application of the definitions established by Directive 2002/73/EC to all areas covered by Directive 2006/54/EC;

5. extending the application of the principle of the burden of proof on the defendant's side to administrative procedures.

An important area directly related to the issue of Community anti-discrimination policy is the recognition of professional qualifications and education. Their (non)recognition is in practice 
one of the most important obstacles to the free movement of persons in the dimension, not only to move unrestrictedly to the territories of other Member States, but indeed to actively participate there in the labour process as a migrant worker (Campina \& Rodrigues, 2021). This situation stems mainly from the differentiation of multi-education European systems and the rather opaque machine of issuing different kinds of certificates of qualifications or education. The permanent nature of this problem also arises from the fact that the system of education is left to the competence of the Member States and is not subject to harmonisation at European Union level.

According to Jančíková \& Pásztorová (2021) in 2005, Directive 2005/36/EC of the European Parliament and of the Council on the recognition of professional qualifications was adopted with the ambition of simplifying and clarifying the system for the recognition of professional qualifications and training, which repealed with effect from 20 October 2007 the existing Directives 89/48/EEC on the general system of recognition of diplomas and No 92/51/EEC on the second general system of recognition of professional qualifications.

Directive of the European Parliament and of the Council no. 2010/41/EU of 7 July 2010 on the application of the principle of equal treatment between women and men engaged in an activity in a self-employed capacity and repealing Council Directive 86/613/EEC, responded to the need to eliminate discrimination on grounds of sex and gender. The issue was covered by relatively large and effective European legislation. As he adds Nováčková \& Vnuková, (2021) measures in this area have a long history at European level dating back to the beginnings of the European Community in the second half of the twentieth century.

In conclusion, however, we consider it necessary to emphasize the importance of Directive no. 2014/54 / EU of 16 April 2014 on measures to facilitate the exercise of rights granted to workers in relation to freedom of movement for workers. As stated in Camarano et al. (2020), this regulation not only significantly extended the scope of anti-discrimination law within the European Union, but in particular enabled individuals to realize their full potential in the European labor market while ensuring equal access to healthcare, education and training as well as housing. He also agrees with this view Dudić et al. (2020) and adds that sexual orientation, religion, disability and age are also the only protected reasons in relation to employment. Therefore, a proposal to extend protection to access to goods and services, also known as the "horizontal directive," is still being discussed in the European Union. 


\section{Conclusion}

In view of the stated objective of our contribution, by analysing scientific and academic literature, legislation and the case law of the European Court of Justice, using the institute of legal logic, we have concluded that the European Union, in its primary and secondary law, explicitly declares equal treatment between men and women as one of the fundamental tasks of the European Community. German national legislation has also been enriched in recent years by transposing a number of anti-discrimination directives and also by amending the Anti-Discrimination Act on several legal institutes, strengthening the principle of equality between men and women in the context of employment relations and in the labour market.

However, the added value of our investigation is a number of serious findings. Antidiscrimination policy in labour law legislation is extremely important, but its enforceability is often complicated and insufficient in practice. We see the cause of this situation in a number of facts. The most problematic can include, in particular, the ambiguous interpretation of certain basic concepts such as direct discrimination, indirect discrimination, equal treatment, equal pay for work of equal value. The relatively low readiness of courts to use new European legislation and caselaw in the resolution of litigation is also problematic. Last but not least, the lack of knowledge of new legislation among the general public, on which discrimination has a direct or indirect impact, prevents the elimination of discrimination. The most effective way to remove these barriers is to increase legal awareness through targeted campaigns, e.g. on social networks.

The issue of eliminating discrimination, especially in employment relationships, is current and will always require constant scientific research. As part of further research, it is necessary to focus our attention on the impact of European legislation and case law on labor legislation in specific countries of the European Union. In our case, it will be a comparative study to the impact of European legislation and case law on the elimination of discrimination in the Visegrad countries after 2015 .

\section{Acknowledgement}

This scientific article was created within the project VEGA [1/0320/21] "The role of universities in building the knowledge economy." 


\section{References}

1. Camarano, A. A., Carvalho, D. F. \& Kanso, S. (2020). Exiting the labour market early: retirement or discrimination? Ciencia \& Saude coletiva, 24 (9), 3183-3192. doi: 10.1590/141381232018249.17452019

2. Chisik, R. \& Namini, J. E. (2019). International trade and labour - market discrimination. Economic Iinquiry, 57 (1), 353-371. doi: 10.1111/ecin.12717

3. Campina, A. \& Rodrigues, C. (2021). The politicization of human rights in the universal pandemic 2020: The relationship between the charter of fundamental rights of the European Union and the international tax law. Juridical Tribune, 11(1), 52-71,

4. Čajka, P., Olejárová, B. \& Čajková, A. (2018) Migration as a factor of Germany's security and sustainability. Journal of Security and Sustainability Issues, 7 (3), 400-408, doi: 10.9770/jssi.2018.7.3(2

5. Dudić, B. Dudić, Z. Pejanović R., Škatarić G., Saxunová D. \& Peráček T. (2020). The rural policy of Slovakia after joining the EU. Agriculture and Forestry, 66 (3), 33-51, doi: 10.17707/AgricultForest.66.3.04.

6. European Council. (1975). Council Directive no. 75/117/EEC on the approximation of the laws of the Member States relating to the application of the principle of equal treatment between men and women. Retrieved March 5, 2021, from https://eur-lex.europa.eu/legalcontent/en/ALL/?uri=CELEX\%3A31975L0117

7. European Council. (1976). Council Directive no. 76/207/EEC on the implementation of the principle of equal treatment for men and women as regards access to employment, vocational training and promotion, and working conditions. Retrieved March 5, 2021, from: https://eur-lex.europa.eu/legal-content/EN/TXT/?uri=CELEX\%3A31976L0207

8. European Council. (1986). Council Directive no. 86/378/EEC on the implementation of the principle of equal treatment for men and women in occupational social security schemes. Retrieved March 5, 2021, from: https://eur-lex.europa.eu/legalcontent/EN/TXT/?uri=CELEX\%3A31986L0378

9. European Council. (1997). Council Directive no. 97/80/EC on the burden of proof in cases of discrimination based on sex. Retrieved March 5, 2021, from: https://eur-lex.europa.eu/legalcontent/EN/TXT/?uri=celex\%3A31997L0080 
10. European Council. (2000). Council Directive no. 2000/43/EC on the implementation of the principle of equal treatment between persons irrespective of racial or ethnic origin. Retrieved March $\quad 5, \quad 2021, \quad$ from: https://eur-lex.europa.eu/legalcontent/EN/TXT/?uri=CELEX\%3A32000L0043

11. European Council. (2000). Council Directive no. 2000/78/EC establishing a general framework for equal treatment in employment and occupation. Retrieved March 5, 2021, from: https://eur-lex.europa.eu/legal-content/EN/TXT/?uri=celex\%3A32000L0078

12. European Court of Justice. (1974). Judgment of 12 December 1974 - Case 36-74. Retrieved March 5, 2021, from: https://eur-lex.europa.eu/legalcontent/EN/TXT/?uri=CELEX\%3A61974CJ0036

13. European Court of Justice. (1974). Judgment of 4 April 1974 - Case 167-73. Retrieved March 5, 2021, from: https://eur-lex.europa.eu/legalcontent/EN/TXT/?uri=CELEX\%3A61973CJ0167

14. European Court of Justice. (1976). Judgment of 8 April 1976 - Case 43/75. Retrieved March 5, 2021, from: https://eur-lex.europa.eu/legalcontent/EN/TXT/?uri=CELEX\%3A61975CJ0043

15. European Court of Justice. (1980). Judgment of 27 March 1980 - Case 129-79. Retrieved March 5, 2021, from: https://eur-lex.europa.eu/legalcontent/SK/TXT/?uri=CELEX:61979CJ0129

16. European Court of Justice. (1981). Judgment of 31 March 1981 - Case 96-80. Retrieved March 5, 2021, from: https://eur-lex.europa.eu/legalcontent/EN/TXT/?uri=CELEX\%3A61980CJ0096

17. European Court of Justice. (1989). Judgment of 28 November 1989 - Case 379-87. Retrieved March 5, 2021, from: https://eur-lex.europa.eu/legalcontent/EN/TXT/?uri=CELEX\%3A61987CJ0379

18. European Court of Justice. (1995). Judgment of 17 Oktober 1995 - Case 450-93. [online]. [cit. 2020-11-09], Available at: https://eur-lex.europa.eu/legalcontent/SK/TXT/?uri=CELEX\%3A61993CJ0450\&qid=1607179164942

19. European Court of Justice. (1998). Judgment of 30 June 1998 - Case C-394/96. Retrieved March 5, 2021, from: https: https://eur-lex.europa.eu/legalcontent/SK/TXT/?uri=CELEX\%3A61996CJ0394\&qid=1607177957377 
20. European Court of Justice. (2000). Judgment of 6 June 2000 - Case 281/98 Retrieved March 5, 2021, from: https:/eur-lex.europa.eu/legalcontent/EN/TXT/?uri=CELEX\%3A61998CJ0281

21. European Court of Justice. (2000). Judgment of 7 December 2000 - Case 79-99. Retrieved March 5, 2021, from: https://eur-lex.europa.eu/legalcontent/EN/TXT/PDF/?uri=CELEX:61999CJ0079\&from=FR

22. European Parliament and Council. (2006). European Parliament and Council no. 771/2006 establishing the European Year of Equal Opportunities for All. Retrieved March 5, 2021, from: https: https://eur-lex.europa.eu/legal-content/SK/TXT/?uri=CELEX:32006D0771

23. European Parliament and Council. (2010). Directive of the European Parliament and of the Council no. 2010/41 / EU of 7 July 2010 on the application of the principle of equal treatment between women and men engaged in an activity in a self-employed capacity and repealing Council Directive 86/613 / EEC. Retrieved March 5, 2021, from: https:/eurlex.europa.eu/legal-content/SK/NIM/?uri=celex:32010L0041

24. European Parliament and Council. (2014). Directive of the European Parliament and of the Council no. 2014/54 / EU of 16 April 2014 on measures to facilitate the exercise of rights granted to workers in relation to freedom of movement for workers. Retrieved March 5, 2021, from:

https://eur-lex.europa.eu/legalcontent/SK/TXT/PDF/?uri=CELEX:32014L0054\&from=NL

25. Fletcher, B. Jr. (2020). Race Is About More Than Discrimination Racial Capitalism, the Settler State, and the Challenges Facing Organized Labor in the United States. Monthly review - an independent socialist magazine, 72 (3) SI, 21-31, doi: 10.14452/MR-072-03-2020-07_3

26. Funta, R. (2018). Extraterritorial application of us-antitrust law on global cartels from comparative (EU LAW) perspective. Lawyer Quarterly, 8 (3), 214-223

27. Gabriel, P. E. \& Schmitz, S. (2020). Are estimates of racial wage discrimination influenced by Labor market conditions? Evidence from the national longitudinal survey. Applied economics letters, 27 (14), 1215-1219, doi: 10.1080/13504851.2019.167637

28. Heath, A. F. \& Di Stasio, V. (2020). Racial discrimination in Britain, 1969-2017: a metaanalysis of field experiments on racial discrimination in the British labour market. British journal of sociology, 70 (5), 1774-1798, doi: 10.1111/1468-4446.12676 
29. Jančíková, E. \& Pásztorová, J. (2021). Promoting eu values in international agreements. Juridical Tribune, 11 (2), 203-218, doi: 10.24818/TBJ/2021/11/2.04

30. Jankelova, N., Jankurova, A., Benova, M. \& Skorkova, Z. (2018). Security of the business organizations as a result of the economic crisis. Entrepreneurship and sustainability issues. 5 (3), 659-671, doi: 10.9770/jesi.2018.5.3(18)

31. Klimek, L. \& Funta, R. (2021). Data and E-commerce: An Economic Relationship. Danube, 12 (1), 33-44, doi: 10.2478/danb-2021-0003

32. Kristinsson, K., Sigurdardottir, M. \& Signalling. S. (2020). Similarity in the Icelandic Labour Market: How Can Immigrants Reduce Statistical Discrimination? Migration letters, 17 (2), 349-356. doi: 10.33182/ml.v17i2.761

33. Luril, M. (2008). Actual development of EU labour law: prohibition of discrimination in labour relations. Proceedings od europeanization of the national law, the Lisbon treaty and some other legal issues conferences, 775-788

34. Mura, L. \& Kajzar, P. (2018), Entrepreneurship in tourism sector in central european country: Hospitality trends in the Czech Republic in 2007-2016. Journal of Environmental Management and Tourism, 9 (6), 1351-1360, doi: 10.14505/jemt.v9.6(30).25

35. Nováčková, D. \& Vnuková, J. (2021). Competition issues including in the international agreements of the eropean union. Juridical Tribune. 11 (2), 234-250, doi: $10.24818 / \mathrm{TBJ} / 2021 / 11 / 2.06$

36. Oláh, J., Hajduová, Z., Lacko, R. \& Andrejovský, P. (2020). Quality of life regional differences: Case of self-governing regions of Slovakia. Sustainability, 2020, 12 (7), 2924, doi: $10.3390 /$ su12072924

37. Peráček, T., Vilčeková, L. \& Strážovská, L. (2020). Selected problems of family business: A case study from Slovakia. Acta Polytechnica Hungarica, 17 (7), 145-162, doi: 10.12700/APH.17.7.2020.7.8

38. Săraru, C.S. (2008). Considera ţii cu privire la limitele libertătii contractuale în dreptul public impuse de integrarea în uniunea europeană. Transylvanian Review of Administrative Sciences, (1), 131-140.

39. Srebalová, M. \& Vojtech, F. (2021). SME Development in the Visegrad Area. Eurasian Studies in Business and Economics, 17, 269-281, doi: 10.1007/978-3-030-65147-3_19 
40. Tekle, T. (2020). The Contribution of the ILO's International Labour Standards System to the European Court of Human Rights' Jurisprudence in the Field of Non-Discrimination. Industrial law journal, 49 (1), 86-112. doi: 10.1093/indlaw/dwz02

41. Troitiño, D.R., Kerikmäe, T. \& Chochia, A. (2018) Brexit: History, reasoning and perspectives, Brexit: History, Reasoning and Perspectives, 2018, 1-283, doi: 10.1007/978-3319-73414-9

42. Žofčinová, V., Horváthová, Z., Čajková, A. (2018) Selected social policy instruments in relation to tax policy. Social Sciences, 7 (11), 241, doi: 10.3390/socsci7110241 